\title{
THE CONCENTRATION OF GLUCOSAMINE IN NORMAL AND PATHOLOGICAL SERA
}

\author{
By R. WEST and D. H. CLARKE with the tech nical Assistance of E. M. KENNEDY \\ (From the Department of Medicine, College of Physicians and Surgeons, Columbia University, \\ and the Presbyterian Hospital, New York City)
}

(Received for publication December 7, 1937)

The development of a convenient colorimetric method for the determination of glucosamine and chondrosamine by Elson and Morgan (1) has made possible the quantitative determination of these substances in sera. In a preliminary communication (2) glucosamine values of 40 to 60 mgm. per cent were reported for normal human sera together with elevated values in the serum of individuals with various infections, advanced malignant disease, and sterile infarcts (coronary occlusion). Palmer and Meyer (3), however, found that the color developed does not obey Beer's law over the range originally suggested, and Palmer, Smyth and Meyer (4) have developed a method which, with slight variations, we have employed. Their values for normal human sera varied from 90 to $130 \mathrm{mgm}$. per cent. Nilsson $(5,6)$ has described a modification of the technique of Elson and Morgan and has determined the glucosamine content of the sera of several animals, and of man. His average value for adult human serum is $77 \mathrm{mgm}$. per cent, for umbilical cord serum $32 \mathrm{mgm}$. per cent, and for pneumonia serum $145 \mathrm{mgm}$. per cent with a maximum of $183 \mathrm{mgm}$. per cent.

Rimington (7) isolated a carbohydrate containing glucosamine and mannose from the proteins of horse serum, but Bierry (8) and S $\phi$ rensen and Haugaard (9) have presented evidence that galactose is also present. Hewitt (10) detected only traces of carbohydrate and no glucosamine in a crystalline fraction of horse serum albumin and describes a carbohydrate rich serum glycoid. Lustig and Langer (11) studied the "sugar" content of various human serum proteins finding increased "sugar" values in patients having carcinoma or pneumonia.

\section{METHODS}

One cc. of serum is diluted to $10 \mathrm{cc}$. with physiological salt solution and $1 \mathrm{cc}$. of the dilute serum is hydrolyzed with $1 \mathrm{cc} .2 \mathrm{~N} \mathrm{HCl}$ for 5 hours in a boiling water bath.
The hydrolysis is carried out in a test tube $(125 \times 16$ $\mathrm{mm}$.) calibrated at $5 \mathrm{cc}$, using a rubber stopper into which has been inserted a small-bore glass tube as an air condenser to prevent evaporation.

At the end of the hydrolysis the tubes are cooled in tap water for a few minutes, distilled water is added to the $5 \mathrm{cc}$. mark, the tube is thoroughly shaken to mix the contents, and the liquid is filtered to remove the coagulum. Then $0.5 \mathrm{cc}$. of the above filtrate is carefully neutralized with $0.5 \mathrm{~N} \mathrm{NaOH}$. A trial titration is used to determine the amount of alkali required.

A stock standard solution of glucosamine hydrochloride containing $10 \mathrm{mgm}$. of glucosamine per cc. is diluted daily to make two standards containing $10 \gamma$ and $20 \gamma$ of glucosamine per cc. One cc. samples of the dilute standards are treated in the same manner as the neutralized serum hydrolysate.

The determination is carried out in $10 \mathrm{cc}$. volumetric flasks which have ground glass stoppers. After neutralization of the hydrolysate, $1 \mathrm{cc}$. amounts of acetyl acetone reagent (1 cc. acetyl acetone dissolved in $50 \mathrm{cc} .0 .5 \mathrm{~N}$ $\left.\mathrm{Na}_{2} \mathrm{CO}_{3}\right)$ are added to the hydrolysate and standards. The stoppers are placed loosely in the necks of the flasks, and the flasks are immersed in a boiling water bath for 25 minutes. A few minutes later, the stoppers are pushed firmly into place to avoid loss of acetyl acetone by evaporation.

At the end of the 25 minute condensation period the flasks are cooled for 2 minutes in water, and 3 cc. of redistilled 95 per cent ethyl alcohol and 1 cc. Ehrlich's reagent $(0.8 p$-dimethylaminobenzaldehyde in $30 \mathrm{cc}$. 95 per cent ethyl alcohol plus $30 \mathrm{cc}$. concentrated $\mathrm{HCl}$ ) are added to each flask. They are shaken gently to mix the contents and placed uncovered for 3 minutes in hot but not boiling water since the alcohol boils violently when heated too suddenly. The flasks are then cooled for 3 minutes, made up to $10 \mathrm{cc}$. with redistilled 95 per cent ethyl alcohol, the tops replaced, and the fluid mixed.

After standing for 30 minutes, the rose color is read in a Klett photoelectric colorimeter using a green glass filter with maximal absorption at $5250 \AA$ reading against the $10 \gamma$ or $20 \gamma$ standards according to the depth of color. Standard curves must be worked out owing to the lack of a linear relationship between color and amount of glucosamine present.

The glucosamine stock standard, the acetyl acetone reagent and the Ehrlich's reagent should be kept in the ice box when not in use. The acetyl acetone reagent should be made up fresh every 3 or 4 days and the Ehrlich's reagent every week or 10 days. 
As previously stated, the failure of the color developed to obey Beer's law made it necessary to prepare special charts. On these, the scale readings of the colorimeter were plotted against $5,10,15$, and $20 \gamma$ glucosamine standards read against each other. The color developed in the serum was read against the nearest $10 \gamma$ or $20 \gamma$ standard, and the value determined from the chart. All determinations were done in duplicate and discarded if they did not agree within \pm 3 per cent.

Samples of serum were hydrolyzed for $1.5,3,5$, and 7 hours to determine the time of hydrolysis suitable for maximal subsequent color development. This was found to be $\mathbf{5}$ hours and included sera with both normal and maximally elevated glucosamine contents. Glucosamine could not be detected in unhydrolyzed serum, nor in the filtrate hydrolyzed after precipitation of the serum with sulphosalicylic acid. This precipitant does not interfere with quantitative development of the color in pure glucosamine solutions nor in hydrolyzed sera. Glucosamine added to serum which was then hydrolyzed for 5 hours was quantitatively accounted for. This was also true for a 6 per cent casein solution, and a 6 per cent casein 1 per cent glucose solution.

Whether all of the color developed by this method in the hydrolyzed serum is due to glucosamine, it is of course impossible to say. However, the peak of the absorption spectrum for the color derived from hydrolyzed serum and pure glucosamine coincide, and heating with alkali destroys the ability of hydrolyzed serum and of glucosamine to develop any appreciable color. All blood samples were collected in the postabsorptive state, excepting those of the pregnant and postpartum women. This was probably an unnecessary precaution as in two individuals the only change in glucosamine concentration before and one hour after a generous breakfast was accounted for by a change in the water content of the serum as judged by serum protein concentration.

\section{RESULTS}

One hundred and eighty satisfactory determinations of glucosamine have been carried out on the sera of normal and pregnant individuals and of patients with various diseases. In the majority of instances the serum protein, albumin, globulin, euglobulin, and fibronogen (12) were also determined together with the erythrocyte sedimentation rate (13).

The resulting values were analyzed with two objects in view, first to determine whether any relationship existed between the level of glucosamine and of that of any of the other serum constituents studied, and secondly, to determine the glucosamine level in normal individuals and the variations from it in disease.

\section{Lack of correlation of the glucosamine level with} serum proteins and sedimentation rate

Glucosamine concentrations were plotted against total serum protein, albumin, globulin, euglobulin, and fibrinogen, and no correlation could be established. There was a tendency for elevation of the sedimentation rate to occur with high glucosamine values, but exceptions were numerous, even in the absence of anemia and of markedly altered fibrinogen levels. The number of determinations and their ranges was as follows: total protein 152 varying from 3.1 to 8.6 per cent, albumin 140 from 1.2 to 5.5 per cent, globulin 140 from 1.3 to 5.2 per cent, euglobulin 140 from 0.1 to 1.9 per cent, fibrinogen 109 from 0.2 to 1.0 per cent, and sedimentation rate 120 from 4 to $130 \mathrm{~mm}$. per hour. The glucosamine values varied from 71 to $210 \mathrm{mgm}$. per cent. It is interesting that glucosamine, which is part of the carbohydrate complex supposed to be attached to some serum proteins, did not vary proportionately with any of the protein fractions studied. This may indicate that fractionation of the serum proteins by Howe's method does not separate chemical individuals, or that the carbohydrate complex may exist as a serum mucoid independently of protein. Hewitt's isolation of a crystalline serum albumin free from carbohydrate, and Kendall's

TABLE I

Serum glucosamine concentration of maternal and umbilical cord serum *

\begin{tabular}{|c|c|c|c|c|c|}
\hline \multirow{2}{*}{$\begin{array}{l}\text { Hospital } \\
\text { number }\end{array}$} & \multirow{2}{*}{$\begin{array}{c}\text { Day post- } \\
\text { partum or } \\
\text { months } \\
\text { pregnant }\end{array}$} & \multicolumn{2}{|c|}{ Maternal serum } & \multicolumn{2}{|c|}{ Umbilical cord serum } \\
\hline & & Glucosamine & Protein & Glucosamine & Protein \\
\hline $\begin{array}{l}518181 \\
513792 \\
491321 \\
389363 \\
522890\end{array}$ & $\begin{array}{l}\text { Day } 1 \\
\text { Day } 1 \\
\text { Day } 1 \\
\text { Day } 1 \\
\text { Day } 1\end{array}$ & $\begin{array}{c}\text { mem. } \\
\text { per cent } \\
94 \\
99 \\
95 \\
104 \\
107\end{array}$ & $\begin{array}{c}\text { erems } \\
\text { per cent } \\
5.2 \\
5.3 \\
5.3 \\
5.8 \\
5.4\end{array}$ & $\begin{array}{c}\text { msm. } \\
\text { per cent } \\
57 \\
59 \\
60 \\
63 \\
64\end{array}$ & $\begin{array}{c}\text { groms } \\
\text { per cent } \\
5.2 \\
5.4 \\
5.7 \\
5.9 \\
6.2\end{array}$ \\
\hline $\begin{array}{l}517966 \\
511418 \\
387816\end{array}$ & $\begin{array}{l}\text { Day } 2 \\
\text { Day } 2 \\
\text { Day } 2\end{array}$ & $\begin{array}{l}144 \\
127 \\
121\end{array}$ & $\begin{array}{l}6.0 \\
6.6 \\
6.2\end{array}$ & $\begin{array}{l}53 \\
67 \\
68\end{array}$ & $\begin{array}{l}\mathbf{5 . 5} \\
\mathbf{5 . 7} \\
\mathbf{5 . 5}\end{array}$ \\
\hline $\begin{array}{l}511990 \\
517836\end{array}$ & $\begin{array}{l}\text { Day } 5 \\
\text { Day } 5\end{array}$ & $\begin{array}{l}127 \\
130\end{array}$ & $\begin{array}{l}6.7 \\
7.1\end{array}$ & $\begin{array}{l}59 \\
64\end{array}$ & $\begin{array}{l}6.5 \\
6.7\end{array}$ \\
\hline $\begin{array}{l}517726 \\
510011\end{array}$ & $\begin{array}{l}\text { Month } 8 \\
\text { Month } 8\end{array}$ & $\begin{array}{l}88 \\
99\end{array}$ & $\begin{array}{l}6.6 \\
7.0\end{array}$ & & \\
\hline
\end{tabular}

* Range of serum glucosamine of normal adults is 75 to $110 \mathrm{mgm}$. per cent. 
studies on $\alpha$-globulin and globulin-X (14) are consistent with this interpretation.

\section{Glucosamine level in normal adult individuals, pregnant women, and their newborn}

Twenty-three determinations of glucosamine and serum protein were made on twenty-one normal individuals aged 25 to 50 years, ten of whom were women. The values varied from 76 to 110 mgm. per cent with an average of 93 . No difference was found between the sexes. The thirteen determinations made in June averaged 90 , the ten from December through March averaged 98, and the level in one individual fell from 110 in December to 76 the following June. Although colds were not noted, subclinical upper respiratory infections may have been present in the winter months. Two individuals showed no variation not accounted for by a change in serum water as judged by protein concentration before and one hour after a large breakfast.

Ten determinations made on umbilical cord blood at birth and on maternal blood postpartum are shown in Table I. The fetal cord serum varied from 53 to $64 \mathrm{mgm}$. per cent, the maternal venous blood serum on the first day postpartum from 94 to 107 . However, on the second and fifth days, values varying from 121 to $144 \mathrm{mgm}$. per cent were obtained. Two women in the eighth month of pregnancy had values of 88 and 99 mgm. per cent. No infected cases were included. The values are higher than those reported by

TABLE II

Serum glucosamine concentration in malignant disease $\nmid$

\begin{tabular}{|c|c|c|c|c|c|c|c|c|}
\hline $\begin{array}{r}\text { Hospital } \\
\text { number }\end{array}$ & Diagnosis & $\begin{array}{l}\text { Glucos- } \\
\text { amine }\end{array}$ & $\begin{array}{l}\text { Erythro- } \\
\text { cyte } \\
\text { sedimen- } \\
\text { tation } \\
\text { rate }\end{array}$ & $\begin{array}{l}\text { Pro- } \\
\text { tein }\end{array}$ & $\underset{\min }{\text { Albu- }}$ & $\begin{array}{l}\text { Glob- } \\
\text { ulin }\end{array}$ & $\begin{array}{c}\text { Euglob- } \\
\text { ulin }\end{array}$ & $\begin{array}{c}\text { Fib- } \\
\text { rinogen }\end{array}$ \\
\hline & & $\begin{array}{c}\text { mgm. } \\
\text { per } \\
\text { cent }\end{array}$ & $\begin{array}{l}\text { mor. } \\
\text { per } \\
\text { hour }\end{array}$ & $\begin{array}{l}\text { grams } \\
\text { per } \\
\text { cent }\end{array}$ & $\begin{array}{l}\text { grams } \\
\text { per } \\
\text { cent }\end{array}$ & $\begin{array}{l}\text { grams } \\
\text { per } \\
\text { cext }\end{array}$ & $\begin{array}{l}\text { grams } \\
\text { per } \\
\text { cent }\end{array}$ & $\begin{array}{l}\text { grams } \\
\text { per } \\
\text { cent }\end{array}$ \\
\hline 536408 & Lymphatic leukemia. W.b.c. 16,000 & 89 & & 7.2 & & & & \\
\hline 436416 & $\begin{array}{l}\text { Multiple myeloma } \\
\text { Liver metastases from carcinoma of breast removed } 2 \text { years } \\
\text { before and carcinoma of cecum removed } 4 \text { months before }\end{array}$ & $\begin{array}{r}99 \\
100\end{array}$ & $\begin{array}{l}94 \\
12\end{array}$ & $\begin{array}{l}7.8 \\
5.7\end{array}$ & $\begin{array}{l}3.3 \\
2.5\end{array}$ & $\begin{array}{l}4.5 \\
3.2\end{array}$ & $\begin{array}{l}0.8 \\
0.8\end{array}$ & $\begin{array}{l}0.3 \\
0.2\end{array}$ \\
\hline $\begin{array}{l}\mathbf{5 2 3 3 3 4} \\
\mathbf{5 2 3 3 9 1}\end{array}$ & $\begin{array}{l}\text { Carcinoma of stomach with liver metastases } \\
\text { Carcinoma of stomach with moderate bone metastases }\end{array}$ & $\begin{array}{l}110 \\
110^{*}\end{array}$ & 30 & $\begin{array}{l}6.1 \\
6.1\end{array}$ & 2.3 & 3.8 & 0.9 & 0.3 \\
\hline 518101 & Lymphatic leukemia. W.b.c. $\mathbf{1 2 , 5 2 0}$ & 113 & 27 & 6.1 & $\begin{array}{l}3.0 \\
4.2\end{array}$ & 2.4 & 0.5 & 0.5 \\
\hline 508528 & $\begin{array}{l}\text { Carcinoma of cervical lymph gland, secondary, following } \\
\text { carcinoma of lung? }\end{array}$ & 120 & $35^{*}$ & 6.4 & 3.8 & 2.6 & 0.7 & \\
\hline $\begin{array}{l}515311 \\
509288 \\
523589\end{array}$ & $\begin{array}{l}\text { Carcinoma of head of pancreas with liver metastases } \\
\text { Lymphatic leukemia. W.b.c. } 6,520 \\
\text { Carcinoma of cecum }\end{array}$ & $\begin{array}{l}127 \\
127 \\
127\end{array}$ & $\begin{array}{l}122 \\
153\end{array}$ & $\begin{array}{l}6.2 \\
7.3 \\
5.8\end{array}$ & $\begin{array}{l}3.1 \\
3.7 \\
3.4\end{array}$ & $\begin{array}{l}3.1 \\
3.6 \\
2.5\end{array}$ & $\begin{array}{l}0.2 \\
0.9 \\
0.4\end{array}$ & $\begin{array}{l}0.6 \\
0.5 \\
0.4\end{array}$ \\
\hline $\begin{array}{l}504628 \\
498548\end{array}$ & Hodgkin's disease & 146 & 53 & & & 1.8 & 0.2 & \\
\hline 513075 & Carcinoma of common hepatic duct & & 45 & 7.0 & 4.0 & 2.9 & 0.2 & 0.6 \\
\hline 274592 & $\begin{array}{l}\text { Hypernephroma of left kidney with metastases to cervical } \\
\text { lymph nodes, humerus, and liver }\end{array}$ & 155 & & & 3.1 & 4.0 & 1.4 & \\
\hline 515229 & $\begin{array}{l}\text { Carcinomatosis with metastases to omentum and lymph } \\
\text { nodes }\end{array}$ & 157 & 44 & 7.2 & 3.2 & 4.0 & 1.0 & 0.4 \\
\hline $\begin{array}{l}522385 \\
511965\end{array}$ & Acute basophilic leukemia. W.b.c. 35,000 & 163 & & 7.5 & & & & \\
\hline 511965 & Reticulum cell sarcoma of all lymph nodes & 163 & $131^{*}$ & $\mathbf{7 . 5}$ & 4.1 & 3.5 & 0.6 & 0.3 \\
\hline 510543 & $\begin{array}{l}\text { Carcinoma of bronchus with extensive metastases to liver, } \\
\text { bones, mediastinum and lymph nodes }\end{array}$ & 170 & $40^{*}$ & 5.5 & 2.9 & 2.6 & 0.5 & 0.2 \\
\hline 506271 & $\begin{array}{l}\text { Carcinoma of stomach with metastases to lymph nodes, } \\
\text { heart, liver, lungs, spleen, pancreas, kidneys, vertebrae } \\
\text { and ribs }\end{array}$ & 172 & 60 & 5.6 & 3.8 & 1.8 & 0.2 & \\
\hline 510615 & $\begin{array}{l}\text { Carcinoma of colon with metastases to liver and mesenteric } \\
\text { lymph nodes }\end{array}$ & 173 & $94^{*}$ & 7.7 & 4.6 & 3.2 & 0.6 & 0.6 \\
\hline 515082 & $\begin{array}{l}\text { Carcinoma of ovary with metastases to peritoneum, bones, } \\
\text { and myocardium }\end{array}$ & 175 & 86 & 5.7 & 3.4 & 2.3 & 0.4 & 0.5 \\
\hline $\begin{array}{r}512625 \\
509775 \\
\text { Private } \\
\text { patient }\end{array}$ & $\begin{array}{l}\text { Carcinoma of lung } \\
\text { Carcinoma of bronchus with very extensive bone metastases } \\
\text { Hodgkin's disease with extensive bone involvement }\end{array}$ & $\begin{array}{l}180 \\
183 \\
195\end{array}$ & $106^{*}$ & $\begin{array}{l}6.5 \\
7.3 \\
8.1\end{array}$ & $\begin{array}{l}4.1 \\
4.3 \\
3.9\end{array}$ & $\begin{array}{l}2.4 \\
3.0 \\
4.3\end{array}$ & $\begin{array}{l}0.6 \\
0.4 \\
1.5\end{array}$ & 0.7 \\
\hline
\end{tabular}

† Range of serum glucosamine of normal adults 75 to 110 mgm. per cent.

* Anemia. 
TABLE III

Serum glucosamine concentration in infections other than pneumonia $\dagger$

\begin{tabular}{|c|c|c|c|c|c|c|c|c|}
\hline $\begin{array}{c}\text { Hospital } \\
\text { number }\end{array}$ & Diagnosis & $\begin{array}{l}\text { Glucos- } \\
\text { amine }\end{array}$ & $\begin{array}{l}\text { Ery- } \\
\text { throcyte } \\
\text { sedimen- } \\
\text { tation } \\
\text { rate }\end{array}$ & Protein & Albumin & Globulin & $\begin{array}{c}\text { Euglob- } \\
\text { ulin }\end{array}$ & $\begin{array}{l}\text { Fib- } \\
\text { rinogen }\end{array}$ \\
\hline & & $\underset{\text { per cent }}{\operatorname{mgm} .}$ & $\underset{\text { per hour }}{m m .}$ & $\underset{\text { per cent }}{\text { grams }}$ & $\begin{array}{l}\text { grams } \\
\text { per cent }\end{array}$ & $\underset{\text { per cent }}{\text { grams }}$ & $\underset{\text { per cent }}{\text { grams }}$ & $\underset{\text { per cent }}{\text { grams }}$ \\
\hline $\begin{array}{l}478973 \\
395722 \\
514573\end{array}$ & $\begin{array}{l}\text { Meningococcus bacteremia, subsiding } \\
\text { Grippe } \\
\text { Tuberculosis, lungs (moderate), lymph nodes and } \\
\text { peritoneum }\end{array}$ & $\begin{array}{r}97 \\
100 \\
121\end{array}$ & $\begin{array}{l}27^{*} \\
11 \\
38\end{array}$ & $\begin{array}{l}7.2 \\
6.7 \\
8.1\end{array}$ & $\begin{array}{l}5.1 \\
4.7 \\
3.8\end{array}$ & $\begin{array}{l}2.1 \\
2.0 \\
4.3\end{array}$ & $\begin{array}{l}0.2 \\
0.5 \\
1.0\end{array}$ & $\begin{array}{l}0.4 \\
0.3 \\
0.4\end{array}$ \\
\hline $\begin{array}{l}\mathbf{4 7 8 9 7 3} \\
\mathbf{5 1 3 5 3 5} \\
\mathbf{3 9 5 7 2 2} \\
\mathbf{5 2 2 4 6 2}\end{array}$ & $\begin{array}{l}\text { Meningococcus bacteremia, febrile } \\
\text { Rheumatic heart disease } \\
\text { Grippe } \\
\text { Rheumatic fever }\end{array}$ & $\begin{array}{l}122 \\
125 \\
127 \\
128\end{array}$ & $\begin{array}{l}63 \\
78 \\
19\end{array}$ & $\begin{array}{l}7.4 \\
7.7 \\
6.7 \\
7.4\end{array}$ & $\begin{array}{l}5.2 \\
4.8 \\
4.7\end{array}$ & $\begin{array}{l}2.2 \\
2.9 \\
2.0\end{array}$ & $\begin{array}{l}0.4 \\
0.6 \\
0.2\end{array}$ & $\begin{array}{l}0.7 \\
0.5 \\
0.4\end{array}$ \\
\hline 506378 & Onset of grippe & 130 & 43 & 6.1 & 3.7 & 2.4 & 0.5 & 0.4 \\
\hline 500599 & Infectious mononucleosis & 142 & 45 & 7.7 & 4.1 & 3.6 & 1.0 & 0.4 \\
\hline $\begin{array}{l}507862 \\
503845\end{array}$ & $\begin{array}{l}\text { Colitis, polyposis } \\
\text { Bacterial endocarditis }\end{array}$ & $\begin{array}{l}142 \\
143\end{array}$ & $90^{*}$ & $\begin{array}{l}6.4 \\
5.8\end{array}$ & $\begin{array}{l}4.1 \\
3.5\end{array}$ & $\begin{array}{l}2.4 \\
2.3\end{array}$ & $\begin{array}{l}0.2 \\
0.5\end{array}$ & $\begin{array}{l}0.5 \\
0.4\end{array}$ \\
\hline $\begin{array}{l}510580 \\
376786\end{array}$ & $\begin{array}{l}\text { Hemolytic streptococcal pharyngitis } \\
\text { Rheumatic fever }\end{array}$ & $\begin{array}{l}145 \\
146\end{array}$ & 47 & $\begin{array}{l}7.6 \\
8.6\end{array}$ & $\begin{array}{l}4.8 \\
4.8\end{array}$ & $\begin{array}{l}2.8 \\
3.8\end{array}$ & $\begin{array}{l}0.3 \\
1.0\end{array}$ & 0.5 \\
\hline 509435 & Rheumatoid arthritis & 154 & 106 & 6.9 & 3.9 & 3.1 & 0.6 & 0.7 \\
\hline 427376 & Lymphogranuloma inguinale & 154 & & 7.8 & 3.9 & 3.8 & 1.3 & \\
\hline 511151 & Chronic ulcerative colitis & 158 & 76 & 7.2 & 4.1 & 3.1 & 0.6 & 0.5 \\
\hline 510580 & Hemolytic streptococcal pharyngitis & 159 & 42 & 8.0 & 5.1 & 2.9 & 0.5 & 0.6 \\
\hline $\begin{array}{l}243838 \\
390321\end{array}$ & $\begin{array}{l}\text { 1 uberculosis, lleocecal } \\
\text { Lymphogranuloma inguinale }\end{array}$ & $\begin{array}{l}161 \\
161\end{array}$ & $\begin{array}{r}38 \\
113\end{array}$ & $\begin{array}{l}7.9 \\
8.0\end{array}$ & $\begin{array}{l}4.0 \\
4.4\end{array}$ & $\begin{array}{l}3.9 \\
3.6\end{array}$ & 1.2 & $\begin{array}{l}0.4 \\
0.9\end{array}$ \\
\hline 511953 & Lymphogranuloma inguinale & 161 & 80 & 8.4 & 4.0 & 4.4 & 1.0 & 0.5 \\
\hline 513259 & Lymphogranuloma inguinale and lues & 164 & 38 & 7.8 & 3.9 & & 0.9 & 0.5 \\
\hline 507336 & Bacterial endocarditis & 165 & 40 & 6.7 & 3.8 & 2.9 & 0.9 & 0.4 \\
\hline 407163 & Rheumatic fever & 167 & 112 & 7.3 & 3.9 & 3.4 & 0.6 & 0.8 \\
\hline 500519 & Periarteritis nodosum & 167 & 94 & 6.4 & 3.8 & 2.6 & 0.4 & 0.6 \\
\hline $\begin{array}{l}508826 \\
514219\end{array}$ & $\begin{array}{l}\text { Acute psoas abscess } \\
\text { Tuberculosis, right upper lobe; pleurisy with ef- }\end{array}$ & $\begin{array}{l}174 \\
175\end{array}$ & $\begin{array}{l}62 \\
25\end{array}$ & $\begin{array}{l}6.7 \\
7.4\end{array}$ & $\begin{array}{l}4.2 \\
4.2\end{array}$ & $\begin{array}{l}2.5 \\
3.2\end{array}$ & $\begin{array}{l}0.5 \\
0.6\end{array}$ & $\begin{array}{l}0.8 \\
0.7\end{array}$ \\
\hline 510876 & $\begin{array}{l}\text { fusion } \\
\text { Gonococcal arthritis }\end{array}$ & 178 & 83 & 8.5 & 4.8 & 3.7 & 1.0 & 0.7 \\
\hline 485198 & Bacterial endocarditis & 178 & $121 *$ & 6.1 & 3.5 & 2.6 & 0.7 & 0.6 \\
\hline 521274 & Lymphogranuloma inguinale & 179 & & & & & 1.0 & \\
\hline 512583 & Rheumatic fever & 180 & 98 & 8. & 4. & & 1.1 & 0.3 \\
\hline 523752 & Rheumatic fever & 182 & 114 & 7. & 3. & 3.2 & 0.6 & 0.9 \\
\hline 500519 & Periarteritis nodosum & 182 & $125 *$ & 6.0 & 3. & 2.4 & 0.5 & 0.4 \\
\hline 341046 & Rheumatic fever & 184 & $135^{*}$ & 8. & 3. & 4.7 & 1.7 & 1.1 \\
\hline 478850 & Rheumatoid arthritis & 187 & & 6. & 4 & 2. & 0.8 & \\
\hline 498482 & Lymphogranuloma inguinale & 187 & $65^{*}$ & 8. & 3.2 & 5.2 & 1.3 & 0.6 \\
\hline 316874 & Bacterial endocarditis & 18 & 100 & 7. & 3. & 3. & 0.9 & \\
\hline 513617 & Acute rheumatoid arthritis & 189 & 106 & 8.1 & 4.2 & 3.9 & 1.3 & \\
\hline
\end{tabular}

t Range of serum glucosamine of normal adults 75 to $110 \mathrm{mgm}$. per cent.

* Anemia.

Nilsson. The elevation of the maternal values on the days following delivery may well represent the reaction of the body to tissue destruction.

\section{Glucosamine levels in various diseases}

Malignant disease. Hodgkin's disease has been arbitrarily placed in this group. Table II presents a summary of the results and shows that cases of early malignancy may have normal values but that with advanced malignancy, the glucosamine level is elevated. Fibrinogen determinations were essentially normal, and the lack of correlation of the glucosamine level with the sedimenta- tion rate, serum protein, albumin, and globulin is clearly shown. Whether the elevation of glucosamine has to do with the malignant process or extensive tissue destruction, it is impossible at present to say, but the latter possibility seems more probable.

Infections. Table III shows the results obtained in infections other than pneumonia. The extent and activity of the infectious process in general parallels rising glucosamine values. It is uncertain whether tissue necrosis or the immune mechanism or both are responsible for the high glucosamine level. Several of the cases of pneu- 


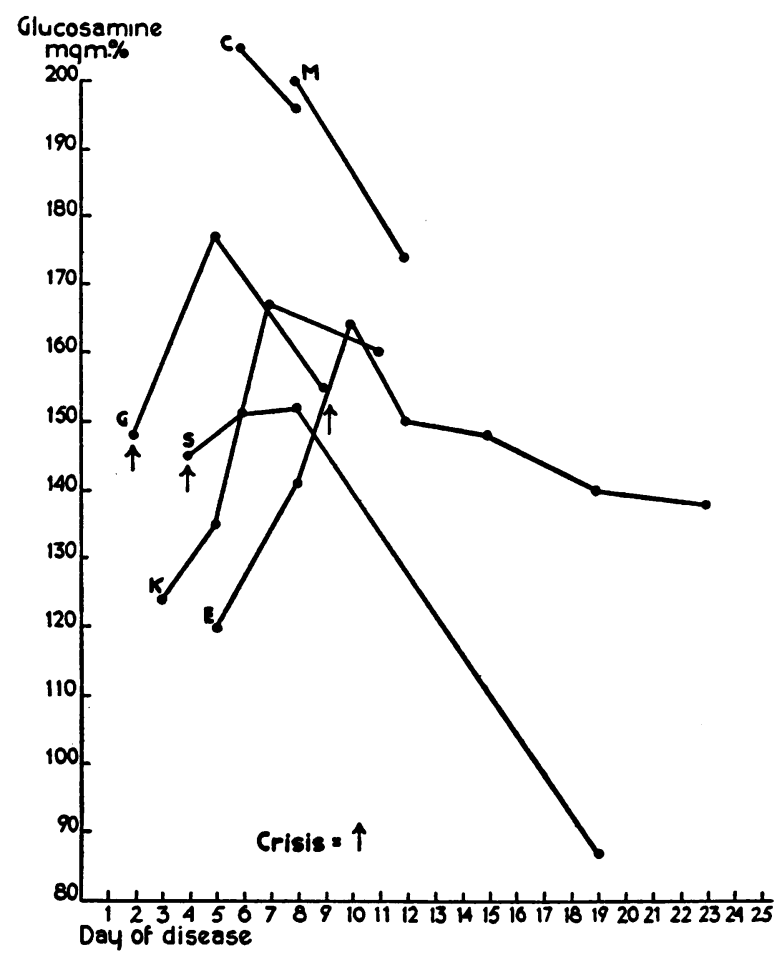

Fig. 1. Serum Glucosamine Level in Pneumonia

$C$-Hospital Number 506687, Type III, positive blood culture; died. $M$-Hospital Number 510503, Type I, empyema, drained Day 20. G-Hospital Number 506309, Type I. S-Hospital Number 509385, Type XVI. $K-$ Hospital Number 508228, bronchopneumonia. E-Hospital Number 514989, Type I, positive blood culture.

monia studied are presented in Figure 1. In addition to glucosamine, total serum proteins and their various fractions were determined. There was a slight decrease in total protein on the third and fourth days of the disease, possibly because of the formation of the exudate, and, as has been previously reported $(15,16)$, a subsequent rise in the globulin fraction and total protein was observed. The glucosamine level was elevated on the second day of the disease and reached its highest value three or four days after the crisis. The rate of return to normal levels varied greatly as Case $\mathrm{E}$ and Case $\mathrm{S}$ show. Unfortunately, it was not possible to study the appearance of antibodies in the serum, and the relative importance of the rôles played by the immune mechanism and the resolution of consolidation remains to be determined.

Coronary occlusion. The three cases with coronary occlusion present the best examples of a sterile infarct. Cases $\mathrm{S}$ and $\mathrm{W}$ clinically represent single infarctions of arteriosclerotic etiology. Case $\mathbf{M}$ probably had a single infarct with a marked pericardial reaction, a rub, some pericardial fluid, and an unusually prolonged elevation of the sedimentation rate. These cases were free from obvious infection and suggest that autolyzing sterile infarcts give rise to high glucosamine values. It is recognized that the changes are not great, but the infarcts are comparatively small, and the larger infarcts encountered were complicated by infection. It is possible that the elevation of maternal serum glucosamine, postpartum, also represents the reaction of the body to the absorption of necrotic tissue.

Miscellaneous conditions. Six cases of Laennec's cirrhosis of the liver, all with inverted albumin globulin ratios, two with marked ascites, had glucosamine values varying from 100 to 137 mgm. per cent. No correlation could be detected with the various protein fractions studied, nor with ascites. Cases with the following diseases had " normal " glucosamine values, that is, 71 to 110 mgm. per cent : pernicious anemia, Ménière's disease, congestive cardiac failure, hyper- and hypothyroidism, pulmonary emphysema, infestation with Clonorchis sinensis, peptic ulcer with hemorrhage, chronic nephritis, Paget's disease (bone), and diabetes mellitus. On the other hand, sev-

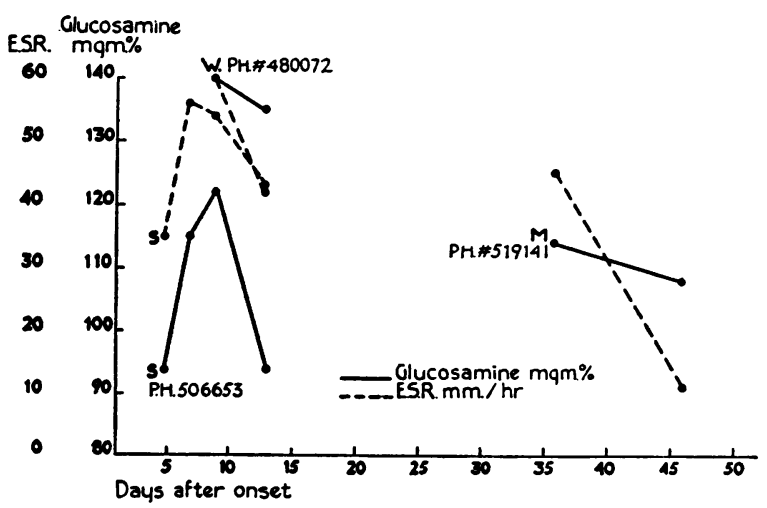

Fig. 2. Serum Glucosamine Level and Erythrocyte Sedimentation Rate in Coronary Occlusion

eral cases of advanced nephritis, nephrosis, and cholecystitis had definitely elevated values. It was extremely difficult to determine whether infection, infarction or thrombosis might not have been present in these last individuals, in addition to their underlying disease. 


\section{SUM MARY}

One hundred and eighty determinations of serum glucosamine have been carried out. In the majority of instances, total protein, albumin, globulin, euglobulin, fibrinogen, and the erythrocyte sedimentation rate were also estimated.

No correlation could be detected between the concentrations of total protein or its various components and that of glucosamine.

There was a tendency toward correlation between the erythrocyte sedimentation rate and the glucosamine concentration of the serum, but exceptions were numerous.

The serum glucosamine level in twenty-one normal adults varied between 76 and 110 mgm. per cent.

Elevated glucosamine values were observed in the sera of patients suffering from infections, disseminated malignant disease, and sterile infarcts.

The level of serum glucosamine in newborn infants is much lower than in adults.

The maternal serum glucosamine level is normal on the first day postpartum, but elevated by the fifth day.

\section{BIBLIOGRAPHY}

1. Elson, A. L., and Morgan, W. T. J., A colorimetric method for the determination of glucosamine and chondrosamine. Biochem. J., 1933, 27, 1824.

2. West, R., The level of glucosamine in normal and pathological sera. Tr. A. Am. Physicians, 1936, 51, 230.

3. Palmer, J. W., and Meyer, K., Estimation of amino sugar. J. Biol. Chem., 1935, 109, 1xxiii.

4. Palmer, J. W., Smyth, E. M., and Meyer, K., On glucoproteins. IV. The estimation of hexosamine. J. Biol. Chem., 1937, 119, 491.

5. Nilsson, I., Zur Bestimmung von Glucosamin in Proteinstoffen. Biochem. Ztschr., 1936, 285, 386.
6. Nilsson, I., Uber den Glucosamingehalt des Blutserums bei Gesunden und Pneumoniekranken. Biochem. Ztschr., 1937, 291, 254.

7. Rimington, C., The isolation of a carbohydrate derivative from serum proteins. Biochem. J., 1929, 23, 430.

The carbohydrate complex of the serum proteins. II. Improved method for isolation and redetermination of structure. Isolation of glucosaminodimannose from proteins of ox blood. Biochem. J., 1931, 25, 1062.

8. Bierry, H., Protéides Plasmatiques et sucre Protéidique. Compt. rend. Soc. de biol., 1929, 101, 544.

9. Sфrensen, M., and Haugaard, G., Uber die Anwendbarkeit der Orcinreaktion zur Bestimmung der Art und Menge von Kohlenhydratgruppen in Eiweissstoffen. Biochem. Ztschr., 1933, 260, 247.

10. Hewitt, L. F., Note on the presence of a new serum protein in the blood of various animals. Biochem. J., 1937, 31, 1534.

11. Lustig, B., and Langer, A., Uber die Bestimmung und den Gehalt an freiem, Eiweiss-und gebundenem Nichteiweisszucker im normalen und pathologischen Serum, Liquor und Harn. Biochem. Ztschr., 1931, 242, 320.

12. Howe, P. E., The determination of proteins in blood -a micro method. J. Biol. Chem., 1921, 49, 109.

13. Westergren, A., Studies of the suspension stability of the blood in pulmonary tuberculosis. Acta med. Scandinav., 1920, 54, 247.

14. Kendall, F. E., Studies on serum proteins. I. Identification of a single serum globulin by immunological means. Its distribution in the sera of normal individuals and of patients with cirrhosis of the liver and with chronic glomerulonephritis. J. Clin. Invest., 1937, 16, 921.

15. Sunderman, F. W., Austin, J. H., and Camac, J. G., Studies in serum electrolytes. I. Concentration of electrolytes and non-electrolytes in the serum during lobar pneumonia. J. Clin. Invest., 1926, 3, 37.

16. Atchley, D. W., and Benedict, E. M., Serum electrolyte studies in normal and pathological conditions: pneumonia, renal edema, cardiac edema, uremic and diabetic acidosis. J. Clin. Invest., 1930, 9, 265. 